\title{
Correction to: Quadrotor Modeling and a PID Control Approach
}

\author{
César A. Cárdenas R., Víctor Hugo Grisales, Carlos Andrés Collazos \\ Morales, H. D. Cerón-Muñoz, Paola Ariza-Colpas, \\ and Roger Caputo-Llanos
}

\section{Correction to:}

Chapter "Quadrotor Modeling and a PID Control Approach" in: U. S. Tiwary and S. Chaudhury (Eds.): Intelligent Human Computer Interaction, LNCS 11886, https://doi.org/10.1007/978-3-030-44689-5_25

The chapter was inadvertently published with an incorrect version of an author's affiliation as "Universidad Manuel Beltrán" whereas it should correctly read "Universidad Manuela Beltrán”. 